\title{
ON THE IGNEOUS ROCKS OF THE WELSH BORDER.
}

\author{
With special reference to the Long Excursion for 1905.
}

By PROFESSOR W. W. WATTS, M.A., F.R.S., SEc. G.S.

(Read July 7th, 1905.)

\section{INTRODUC'TION.}

$\mathrm{I}_{\mathrm{N}}$ studying the igneous rocks of any extensive area in the 1 attempt to elucidate its volcanic history there are three great principles to be borne in mind.

I. That there is usually a time relation between earthmovement and vulcanicity.

2. That the location of the vulcanicity is definitely related to the direction and intensity of the movement.

3. That there is a tendency for earth-movements to recur at the same place, and often in the same sense, in different geological periods, and that, therefore, there will be a corresponding tendency towards the local recurrence of igneous phenomena.

I. The four great periods of earth-movement in Britain which have left their marks in Wales are the Post-Archæan, the PostOrdovician, the Post-Carboniferous, and the Post-Eocene. Three of these periods, if not the fourth, have been accompanied by volcanic action. With the first are associated the Longmyndian and Uriconian volcanic rocks, with the second the great outburst of volcanoes during the Ordovician Period, and with one or both of the last two periods possibly certain rocks in Pembrokeshire and others which project a short distance into Wales from the eastern border.

2. In the classic instance of the Bala volcanic rocks, Mr. Harker* has demonstrated that the Snowdonian vulcanicity was ruled by the existence of resisting "breakwaters" such as that of Llanberis, against which the earth-wave broke, producing a line of vents running from Penmaenmawr, through Foel Fras, to Mynydd Mawr and perhaps beyond. I believe that a corresponding though less evident association can be traced in connexion with the great anticlinal masses out of which the structure of Wales is built up. These masses run on the whole N.E. to S.W., and may be grouped as follows: (a) The Llanberis anticlinorium; (b) the Harlech anticlinorium; (c) the Berwyn anticlinorium; $(d)$ the Longmynd-Builth anticlinorium; $(e)$ the anticlinorium of the Malvern fracture-line; and lastly $(f)$ the St. David's anticlinorium.

" "The Bala Volcanic Series of Caernarvonshire," Cambridge, $\mathbf{8 8 9 g .}$ 
The word anticlinorium is used in preference to the simpler term anticline, because the structure of each of these areas is complex, as is well known, and in particular because there are often smaller associated synclines such as that of Menai, usually devoid of igneous rock. There are also smaller attached anticlines like that of Old Radnor and the Wrekin. Moreover, there are associated faults such as those of Bala, Berwyn, Breidden, and the Lilleshall-Caradoc-Radnor fault.

3. Whatever may have been the primary origin of these anticlinoria, three things are quite certain;- that they are very ancient; that they have been persistent throughout geological time, indeed they might also be called pertinacious; and they have been again and again associated with volcanic action. Shropshire furnishes an example which is typical of the other areas. Without entering into the vexed question of the relations of the Longmyndian and Uriconian Rocks we are sure that these rocks were being denuded in shallow water to furnish the basal beds of the Cambrian; so the Longmynd area was brought into the reach of denudation, for the first time within our knowledge, by Cambrian or Pre-Cambrian movement. The unconformity of the Bala beds on Uriconian and Cambrian Rocks on the east side of the Longmynd proves that N.E. to S.W. movement was going on in Ordovician times, just as has been shown by Harker in Caernarvonshire. Nowhere has this movement, recurring in Post-Ordovician times, produced more marked effects than in the Silurian unconformity of Shropshire. And there is plenty of evidence of movement, land, and denudation, in Carboniferous, Permian, and Triassic times. Later than this we are without evidence.

Three of these periods of activity at least were accompanied by vulcanicity of a complicated character, and extending throughout a long geological interval, and in most of the anticlinoria not less than two, and sometimes all three, volcanic episodes are represented. Although in each area the volcanoes of a particular period had a definite local sphere of activity, their products are not by any means confined to such spheres, but encroach on those of previous episodes. This has given rise to a series of difficulties in the geology of Wales, hardly less serious than those resulting in the stratified rocks from the complicated geological structure of the ground. Many of the mistakes already detected in the interpretation of the geology of Wales have come from ignorance of this fact, and the recognition of it in different regions by Ramsay, Hicks, Bonney, Callaway, Harker, Lapworth, and others, marks the successive stages in the right knowledge of the country. Even yet many difficulties remain in the more complicated districts ${ }_{y}$ for, unlike the sedimentary rocks, no datestamp appears to have been used in the manufacture of igneous rocks. 


\section{THE LLANBERIS ANTICLINORIUM.}

It will be sufficient to refer the reader to Mr. Harker's* Memoir on "The Bala Volcanic Rocks of Caernarvonshire" for a complete description of the phenomena of this tract. Two masses of Archean igneous rock occur here, one stretching S.W. from Bangor, and a second running N.E.-S.W. through Llyn Padarn. The rocks are mainly felsites and quartz-porphyries associated at Caernarvon with granitic rock. The eastern mass is flanked by the Snowdonian (Bala) tuffs and lavas, mainly of acid composition, extending between Conway and the Lleyn. Large intrusive masses of plug-like type run parallel and to the N.W. of the Snowdon range, and there are numerous intrusive acid and intermediate rocks such as granites, syenites, and granophyres. There are also more basic intrusions ranging from andesites to dolerites, gabbros, and picrites, which are PostOrdovician and probably Post-Silurian in age. Younger intrusive dykes, probably Post-Carboniferous, if not later, are found in Anglesey.

\section{THE HARLECH ANTICLINORIUM.}

The mass of sedimentary Cambrian rock in the core of this anticline is penetrated by numerous dykes and sills of igneous rock. It is flanked by the products of a great series of volcanoes, entirely from the Moelwyns and Manods, through Arenig and Aran, to Cader Idris. These eruptions, $\uparrow$ according to Cole, began in Tremadoc times, but were most active in Arenig or Llandeilo time. As usual there are approximately contemporaneous plutonic intrusions, such as the granite of Tan-y-Grisiau, and later intrusive sills and laccolites of basic material, usually dolerites and gabbros devoid of olivine. The volcanoes of the period appear to have been situated around the anticline, and not to have encroached upon the core to any great extent. Later igneous rocks have not been detected for certain in the area, and even the Bala rocks are non-volcanic here.

\section{THE BERWYN AN'TICLINORIUM.}

\section{A. The Berwyns.}

The most recent notice of the igneous rocks of this area is that by Messrs. Cope and Lomas, which appears in abstract in the Annual Report of the British Association for 1903. The rocks occur as an incomplete dome showing, according to the Geological Survey Map, tuffs and intrusions in the middle,

* Vol. cit.

$\dagger$ Geol. Mag., Dec. 3, vol. iii, 1886, p. 2 rg. 
probably of Arenig or Llandeilo age, and round the outer edge other tuffs, of Bala age, also associated with intrusive rocks. Messrs. Cope and Lomas, however, have failed to find any evidence of contemporaneous volcanic activity. They regard the rocks as intrusive, with fragments of sediments caught up in them, or else with flow-brecciation; the rocks have also been much crushed. The rock-types are diabases, rhyolites sometimes nodular, and perhaps rocks of intermediate composition. They present many resemblances to those described by Hatch and others in Wicklow and Wexford. The authors conclude that the intrusions are pre-Wenlock.

\section{B. The Breiddens.}

This little district forms a bridge between the Berwyn area and that of Shelve. It is almost certainly bounded by a large fault on the west along the line occupied by the Severn Valley, as instead of the Llandeilo or Arenig rocks, which should occur to the west, Silurian rocks are found there. Contemporaneous tuffs and agglomerates are interbedded with Bala beds, these fragmental rocks yielding fossil evidence of submarine origin. There are also interbedded andesitic lavas closely related to those of the Stapeley and Todleth Ridge in the Shelve country. Piercing the other rocks there are hypersthene-diabases certainly PostBala in date and almost certainly Post-Llandovery. These occur as sills and laccolites, the fine crags of Rodney's Pillar Hill being the best example of the former.

Mr. Jevons, * finding the felspar in two specimens of the "andesites" of Moel-y-Golfa to be albite, determines these rocks as keratophyres, and he extends the same conclusion to those sills of the Berwyn area which have been called diabases. $\mathrm{He}$ also hazards the conjecture that the intrusive rocks called diabases by the writer in the Breiddens may belong to the keratophyre group. If correct these determinations will do something to unify the types of Ordovician and Post-Ordovician rocks of different areas, since keratophyres undoubtedly exist in the Wicklow and Wexford areas, in the Pembrokeshire district, and, as Rosenbusch indicates, will undoubtedly be found in Snowdonia and possibly in the Arans and Arenigs.

\section{THE LONGMYND-BUILTH ANTICLINORIUM.}

\section{The Post-ARchrean Rocks.}

These rocks are distributed at intervals round the Longmynd, from Lilleshall, through the Wrekin and Caradoc, to Warthill Knowl on the east, and from Pontesford Hill to Knolls Wood on 
the west. They consist of rhyolites in the main, interspersed with andesites and more basic rocks. Many descriptions of portions of these rocks have been given by various writers, but the only one which combines the result of detailed field-mapping with petrographical work is the account of Pontesford Hill, by Professor Boulton.* For our present purpose that area may be selected as a type. Even here it was not always possible to discriminate between interbedded and intrusive rocks, but the former seem to include not only rhyolites, but andesitic rock of varying degrees of acidity, together with acid and intermediate tuffs and palagonite tuffs. Intrusive into this series are olivine-dolerites, which Boulton likens to those associated with Carboniferous rocks in many border localities. More or less similar rocks and associations are found in other masses such as the Wrekin and Caer Caradoc. Numerous intrusive rocks have been noted in the Longmynd country, and described by $\mathrm{Mr}$. Cobbold, $\dagger$ in part from microscopic descriptions of the writer. Many of these are olivine-dolerites of the type just mentioned, but there is one type worthy of special note, a hornblende-diorite or camptonite related to those of Nuneaton. This rock-type has also been found in contact with Uriconian rocks at the Lickey, and with Cambrian quartzites and shales at the Wrekin and Malvern, but never with anything more recent, so that it probably represents the last phase of Post-Archæan activity. Neither lavas nor tuffs are known in this area amongst Cambrian rocks, and this period appears to have been one of tranquillity.

\section{Ordovician and POST-Ordovician Rocks.}

\section{A. THE SHELVE AREA.}

As is the case in North Wales the vulcanicity broke out during two maxima, one in the Arenig and the other in the Bala Period, the intervening Llandeilo Period showing evidence of merely local and sporadic outbursts. The rocks are almost exclusively andesites in the form of lavas and tuffs, with some intercalations of trachytic rocks and a few breccias made up of rhyolite fragments. The lower volcanic band occurs just below the zone of Didynograpius Murchisoni, and the higher one well up above the base of the Bala. The tuffs are fossiliferous in both cases and were deposited under marine conditions. The last stages of vulcanicity were marked by the intrusion of sills, laccolites, and dykes, along surfaces of movement due to folding, faulting, and torsion. 'The earlier of these are hypersthene-and

"Quart. Journ. Geol. Soc., vol. 1x, I9c4, p. 45 ".
+ Caradoc and Severn Valley Field Club, "Recor 1 of Bare Fasts," $1994-2836$, vide also Churcb Stretton, Shrewsbury. 
augite-diabases similar to those of Snowdonia; these have been found in contact with Silurian Rocks and are hence Post-Silurian in date. The later are more basic and pass into augite-picrites, but it has not been possible to ascertain their age. Most of the associated sediments such as the Lower Arenig fiags and the basal Llandeilo grits are mainly made up of volcanic débris, and sometimes contain bands of china-stone ash, and genuine tuff.

\section{B. The Caradoc Area.}

In this area there are no known Arenig or Llandeilo rocks, and the base of the Bala rocks rests unconformably on older strata; hence this area was land during earlier Ordovician time. But, as at Pontesford, there are basic rocks intrusive among the Uriconian rocks which are of unknown age. Many of the Caradoc Sandstones are made of volcanic material which cannot have travelled far from a volcano, and the more ashy beds are proved by their fossils to be contemporaneous with the Bala ashes of the Shelve District on the west side of the Longmynd.

\section{c. The Builth Arka.}

The igneous rocks of the southern part of this district were described by Mr. Woods* in 1894, and that author found that they were related in character to those of the Shelve region. There are andesitic ashes which appear to be at the top of the Arenig strata, underlying beds containing Llandeilo fossils; andesites closely related in composition to the ashes, but apparently intrusive into them; rhyolites and rhyolitic ashes; and intrusive masses of diabase-porphyrite and of diabase. It does not appear that the andesites, though intrusive, are very far separated in point of age from the ashes of similar composition, a relationship which seems to prevail in Shropshire and at Arenig itself. No Bala rocks were found by Mr. Woods. The diabases are thought by Mr. Woods to be Post-Llandeilo and Pre-Silurian in age.

Farther to the south-east igneous rocks were discovered by Murchison, and mapped by the Geological Survey; one group near Llanwrtyd, about ten miles W.S.W. of the Builth area; a second near Llangadock, half way between Llandeilo and Llandovery; and a third group about six miles S.W. of Caermarthen. Of these areas no recent descriptions have been published.

\section{Other Igneous Rocks.}

A very remarkable group of igneous rocks about which there is much difference of opinion was visited by the Association in I904 near Kington and Old Radnor. These rocks were briefly

\footnotetext{
* Quart. Jouru. Geol. Soc., vol.1, 1894, p. 566.
} 
noted by Callaway* in $\mathbf{1 8 7 9}$, and afterwards described in outline by Professor Cole† and Mr. F. Raw. ${ }_{+}^{+}$Dr. Callaway subsequently claimed the hard greywackes of Old Radnor as Longmyndian in age, and showed that they were unconformably covered by sediment partly belonging to the Llandovery epoch. Associated with them there are acid and basic rocks of uncertain age, the former being felsites and granophyres, and the latter "augite-diorites," diabases, and gabbros. This group of rocks was referred by Dr. Callaway with hesitation to the Pre-Cambrian Period, but it is interesting to note that both Murchison and Cole in describing the rocks find the majority of their comparisons in Skye. This and other evidence, though far from conclusive and indeed rather of the nature of suggestion than proof, makes it desirable to consider the possibility that these rocks may belong to the Tertiary group.

There is in the Midlands a group of olivine-dolerites of which it is difficult, if not impossible, to ascertain the age. They are generally intrusive into the Coal-measures, and thus cannot well be earlier than Permian. But they are altogether different from such known Permian igneous rocks as those of Devon and South Scotland. If they should belong to the Mesozoic Period they would be unique in Britain, for this was an era of remarkable tranquillity both in respect of organic movement and vulcanism. Moreover, certain undistinguishable rocks occur in the Leicestershire coal-field intrusive between Coal-measures and Trias, and at Butterton and Swinnerton, in Staffordshire, actually intrusive into Permian and Triassic Rocks. In seeking for evidence of age for one of the chief of these dolerites, that of Rowley Regis, Jukes found that while intrusive into Coal-measures this rock was disturbed by the latest earth movement that had been felt in that area. Such movement may well be Tertiary in date, as it cuts into the neighbouring Jurassic Rocks and is parallel to faults and folds which traverse more distant Cretaceous and Eocene Rocks. Further, Allport, in examining the petrology of these rocks could find no points of difference between them and the known Tertiary dolerites of Antrim and the Inner Hebrides.

Again similar rocks are not infrequently associated with very ancient rocks in the Isle of Man and Ireland, and may be traced from thence into the neighbourhood of the Tertiary rocks of Scotland and Antrim. It has been more than once suggested by the writer that in default of evidence to the contrary it may be well to keep in view the possibility that this group of olivinedolerites may be of Tertiary age. Now if a line be drawn from the southern part of the Leicestershire Coalfield to Rowley and Wednesbury, it will pass through the similar rocks of Kinlet and

* Quart. Journ. Geol. Soc, vol. xxxv, I879, p. 643.

+ Geol. Mag., Dec. iii, vol. iii, I886, p. 219 .

+ Proc. Geol. Assoc., vol. xvii, Igo4.

\$ Quart. Journ. Geol. Soc., vol. Ivi, 1900, p. 5Ir. 
the Clee Hills, and if produced it will cut into the Old Radnor area. That is to say, a group of olivine-dolerites undistinguishable from the Tertiary lavas and intrusive rocks of Skye or Antrim falls into line with a group of rocks closely comparable with the intrusive bosses and laccolites of Skye or Barnavave or Carlingford. An almost parallel band would include the Butterton dyke, the olivine-dolerites of Little Wenlock and the Wrekin, and the similar rocks which have been mentioned as intrusive into the Archæan rocks of Caradoc and the Longmynd. Such a line would run parallel with that drawn by Harker in his recent Memoir to limit the extension of Tertiary volcanic rocks according to present knowledge. It would lengthen the radius of this area by forty miles. Thus a broad belt may exist along which Tertiary vulcanicity endeavoured to assert itself wherever weak places existed as manifested by the protrusion of ancient rocks along the belt. If this course of argument is permissible it may be that many of the later intrusive rocks associated so frequently with Archæan rocks in Midland England and Wales may be of Tertiary age.*

\section{VI, THE MALVERN ANTICLINORIUM.}

The only igneous rocks exposed along this important line are those about Malvern and at Tortworth, the former belonging mainly to the Post-Archæan and the latter to the Post-Ordovician type. Tracing the anticline from north to south the basal rocks along the line are Silurian at Abberley and Tortworth, crystalline Archæan at Malvern, and Longmyndian (according to Dr. Callaway) at May Hill.

\section{A. The Malverns.}

The core of the Malvern Hills consists of a highly complex plutonic and gneissose series into which doubtless many later rocks have been intruded. Callaway, Green, Rutley, Acland, and Groom have described the rhyolitic tuffs, andesites and basalts, of Herefordshire Beacon, which seem to be similar to the typical Uriconian rocks. No later contemporaneous volcanic rocks have betn discovered and the Ordovician rocks seem to be absent from the region. Intrusive into the Cambrian rocks, however, are numerous sills and dykes of several rock-types, including camptonites of the Nuneaton character ("amphibole-bearing rocks of andesitic habit") $\dagger$ augite-basalt, olivine-basalt, and olivinediabase. Groom thinks it likely that these rocks are Pre-Silurian but it appears possible that while certain of the rocks are of this date some of the series, as elsewhere, may be younger. 


\section{B. TORTWORTH.}

Our latest account of the rocks of this district is by Professors Lloyd Morgan and Reynolds.* They find that tuffs occur on two horizons, one group covered by strata of Upper Llandovery age, and the other by beds of Lower Wenlock age. Associated with these are highly, decomposed and amygdaloidal lavas generally about intermediate in composition, and classed either as pyroxene-andesites or as basalts. Part of the pyroxene in these rocks is rhombic, thus furnishing a link with the PostSilurian intrusions of Shropshire and elsewhere. This rock group is of remarkable interest as it presents the only example of effusive rocks of Silurian age in Great Britain.

\section{THE ST. DAVID'S ANTICLINORIUM.}

A very brief note and reference to authorities in this area must suffice for our present purpose. Hicks, Teall, Rutley, Reed, Parkinson, Elsden, Howard, and Snall have all dealt with portions of the region.

\section{A. The St. David's Area.}

The Archæan complex includes granitic rocks, rhyolites, and intrusive basic rocks. The north-easterly prolongation of the anticline is flanked by bedded and volcanic rocks belonging to two horizons in the Ordovician, the lower associated with the zone of Didymograptus Murchisoni, and the higher classed by Mr. Reed ${ }_{T}^{+}$with the Upper Llandeilo and Lower Bala. These rocks seem to be chiefly felsites and rhyolites, often nodular and spherulitic. The intrusive rocks cover a wide range in composition, and have recently been considered in detail by $\mathrm{Mr}$. Elsden.\$ The oldest of the intrusions are lime-bostonites, which are more basic than the keratophyres of south-eastern Ireland, but seem to be related to them. These were followed by gabbros and norites, and these again by the intrusion of the great basalt laccolite of Pen-Caer. Amongst the intrusions Mr. Cowper Reed found variolitic rocks. There appears to be no precise evidence of the age of the intrusive rocks.

\section{B. The Skomer and Mrlford Areas.}

Work has been done recently in this area by Messrs. Howard and Small.§ They find interbedded rhyolites and basalts, and

* Ibid, p. 26\%.

+ Quart. Journ. Geol. Soc., vol. 1i, I895, p. 149.

$\mp$ Abstract Proc. Geol. Soc., 1904, p. 95 .

Annual Rep. Brit. Assoc. for I8g6, p. 797. Trans. Cardiff Nat. Soc., vol, xxvili, 1896 , and vol. $x \times 1 x, 1897$.

Proc. GeOL. ASSOC., Vol. XIX, PART 3, I905.] 
plutonic rocks such as granites and quartz-diorites. They seem to be unable to find any precise date to the vulcanicity, and there exists a bare possibility that the rocks may be due to the PostCarboniferous movement.

\section{CONCLUSIONS.}

On reviewing the igneous rocks of Wales and its border counties and countries there are a few conclusions which have forced themselves on the writer.

I. The Irish Sea is girt with a belt of igneous rock of various ages, the ring being more complete in Wales and south-east Ireland than elsewhere. Here, indeed, a buckling of the ring is produced by the projection of the Lleyn towards Wicklow and the southern basin of the Irish Sea is thus defined. This part of the ring, however, not only encloses this basin but all Central Wales as well, which is devoid of any igneous rocks whatever.

2. In Wales itself the igneous phenomena are generally associated with the principal anticlinoria, of which six have been considered in more or less detail.

3. As a general rule the volcanoes were situated round the edge of the anticlines, where such roots as have been discovered are mainly situated. Doubtless the lavas and tuffs originally spread to some extent over the cores of the anticlines, from which they have been removed by denudation, but the scarcity or smallness of the later intrusive rocks inside the anticlinal areas seems to show that the volcanoes themselves were marginal they are a phenomenon of the "middle limb." The Berwyns appear to present an exception to this rule, but in this case the anticline may be of later date than the others, and the type of vulcanicity is exceptional.

4. Most of the anticlinoria have again and again been the foci of the vulcanicity of successive periods, but there is a decided tendency for them to progressively migrate towards the exterior.

5. The Post-Carboniferous vulcanicity does not appear to have anywhere penetrated far into Wales, possibly because the movement was not sufficiently "strenuous" to affect the already moved ancient rocks of the region. The most probable exception is that given by the rocks of Skomer and Milford, where we come within the scope of the greater power of the Armorican movement. With the exception of South Scotland, the volcanic action of this period does not appear to have had great power, and the igneous rocks of Devon and Derby give evidence of only very feeble action.

6. The tremendous earth-movement and volcanic outburst of Tertiary times developed on such a gigantic scale on the flanks of the northern prolongation of the Irish Sea, and of the northern 
basin of the sea itself, succeeded in forcing its way inwards, and thus we find what are almost certainly Tertiary igneous rocks not only on the borders but inserting themselves right into the heart of the older igneous masses.

7. It is this "ring-fence" of volcanoes, and the mountain masses which have resulted from them, which have been responsible for preserving the individuality of the country. If the rivers which come from within had not themselves breached this single, double, or even triple rampart, Wales would have held the invader outside her fastness even longer, though certainly not more bravely, than she did. 
Plate V.-GEOLOGICAL MAP OF THE RHAYADER DISTRICT.-Herbert Lapworth.

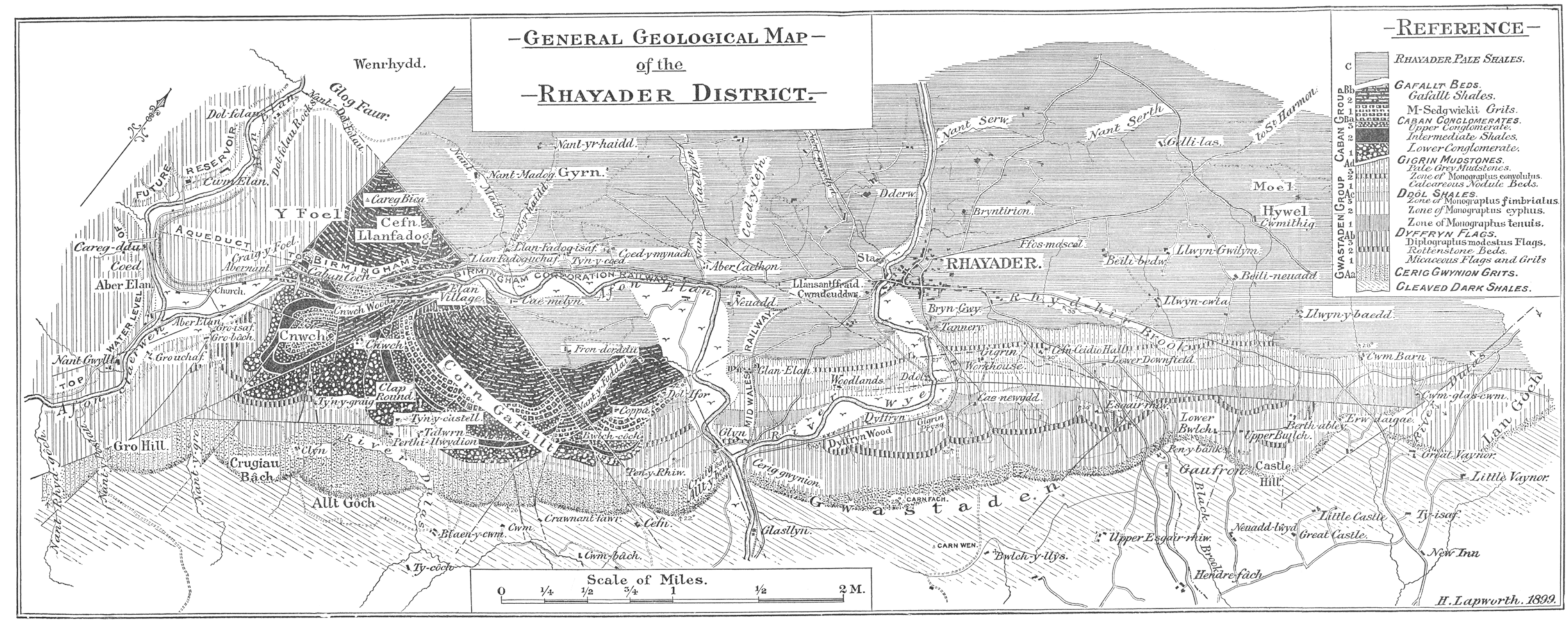

